\title{
On the Role of Traditional Cultural Value System for Ideological and Political Education of College Students
}

\author{
Xiaoshi $\mathrm{Xu}^{1}$ and Le Gao ${ }^{1^{*}}$ \\ ${ }^{1}$ College of Marxism, Jilin Agricultural University, Changchun 130118, China \\ L. Gao, associate professor, female, born in August, 1974, interested in ideological and political \\ education
}

*The corresponding author

Keywords: Traditional cultural; Value system; Students; Ideological and political education

\begin{abstract}
Traditional values, as the soul of Chinese cultural spirit and the core of ideology, leave a great legacy for the contemporary people. It is a very complicated and difficult task to evaluate this heritage. Since modern times, when there is a national social danger or turn, it will cause the argument of traditional culture and traditional values, which fully shows that it is an unavoidable and insurmountable problem in the process of China's social development. [1] Today we are still facing this serious topic, no matter what is the historical destiny of traditional values, and what isthe development prospects of modern values, what we need is calm and scientific attitude.
\end{abstract}

\section{Introduction}

Ideological and political education work is improved through leading contemporary college students to learn Chinese traditional culture knowledge, which will help to guide the contemporary college students' outlook on life, moral concept, knowledge concept, aesthetic standard, the formation of knowledge concept and the natural values. It is very effective for ideological and political education of contemporary college students. Based on the value system of Chinese traditional culture, this paper analyses the positive role of the value system of Chinese traditional culture in the process of contemporary college students' ideological education. [2]

\section{Value System of Chinese Traditional Culture}

Chinese culture has experienced several thousand years of development, and it is constantly changing with the evolution of times, but it always maintains the Chinese traditional stability factor, hiding the basic characteristics and personality different with other nationalities.

Value system is the overall organic combination of various value factors. The formation and development of values have close relations with production mode, social structure, cultural background and other external factors, and the concept of value system mainly focus on interrelation and interaction of internal factors in value world, and the unified whole formed by these factors.

Basic types of Chinese traditional values. Confucian values for self-cultivation and going into the society. Chinese traditional culture is essentially the culture with Confucian traditional culture as the main shaft. The traditional Chinese values is essentially the values taking Confucian value as the leading. The biggest characteristic of Confucian values is to emphasize people's moral consciousness, asking people to consciously do self-discipline in accordance with the code of ethics "benevolence", in order to achieve the improvement of the heart. This is the Confucius' thought of "self-accomplishment basis". [3]

Taoists values for inaction and retiring from the world. Taoist thought in China has a profound social soil, and the values of Taoist inaction and retiring from the world can fit Chinese deep psychology, so its influence is more profound. The Taoist thought is a kind of natural inaction. Although Taoism advocates inaction, it does not mean they have no value pursuit. First of all, inaction itself is a kind of value pursuit. and only inaction is in line with the value of Taoist ideas. 
Secondly, the inaction is also a kind of action, and inaction is just for the purpose of all actions.

Extraordinary refined Buddhist values. Buddhism is the most widely circulated foreign religion in China, and values of Buddhism in China also have considerable influence. Buddhism thinks social family life of human and personal life is full of suffering, everything is uncertain, and everything is absolute nothingness. The logic conclusion is necessarily and completely denying the world without practical significance. It denies the reality of all values, of course also denies people's self-worth with complete retiring attitude.

\section{The Influence of Chinese Traditional Culture on Ideological and Political Education}

Filial Piety Basis. In China with traditional and deep patriarchal clan system and tough kinship ties, filial piety concept has a pivotal position, and it is the highest principle of Chinese traditional ethics, as well as the core of Confucius ethics theory. The value significance contained in filial piety basis is also very important for college students' ideological and political education. It will also help to carry out the ideological education work by strengthening the implementation of college students' ideological and political education work and guiding students to establish correct thought of filial piety. [4]

Self-cultivation and Loving People. "Self-cultivation" is self-improvement for of moral sentiment, in particular, it is to achieve "benevolence". People should use ritual to discipline themselves to try to do all in word and deed shall conform to the specification of ritual. Self-cultivation is not to show others, and should be a self-conscious pursuit; therefore, even if staying alone without others' supervision, people should keep inner concentration. That is to say people can't break ritual at any time. For the ideological and political education of college students, self-cultivation and loving people is not only to strengthen self-regulation of mind and body, do four haves youth, and law-abiding qualified "citizens".

Colony Standard. One of the essential characteristics of traditional Chinese values is emphasizing groups and underestimating individual. It indicates that individual is the role distributed by society and has group survival needs, and is the interactive individual with ethical and moral consciousness. Colony standard values is in a very important position during the process of ideological and political education. It can help develop the national sense of responsibility, national integrity, suffering consciousness and sacrificing spirit for the society by strengthening the guide of college students' colony standard. [5]

The Golden Mean. The basic principle of golden mean is sincerely hold the fast due mean, and the moderate limit should be held. Golden mean requires people to consciously regulate personal thoughts and feelings, and behavior and speech according to certain code of conduct and value standard. Golden mean is a code of ethics, having certain positive meaning. In the field of ethics, it acknowledges interdependence and mutual connection of moral, and affirms the ethical behavior should be moderate, which is worth reference by today's construction values. At the same time, for students setting up the correct through, behavior standard, it also has important reference value. [6]

Equality, Morality and Justice, Material Gain. Yi refers to morality and justice, namely the maintenance of ethical code of traditional system; Li refers to the immediate interests of people and the actual material gain. In China, because of the influence of traditional concept of richness, morality and justice, poverty and material gain, Chinese people have mentality that are ashamed to talk about the material gain, and always consider it as the representation of villain. When talking about it, the personality seems become small. But real life always cannot leave a material interest, so it often causes the split of personality or the dualism of personality. The concept of equality, morality and justice, material gain will help to guide students to set up the correct values, guide them forming completely independent personality for the ideological and political education of college students. [7]

Exploration and Continuous Pursuit. In traditional Chinese values, the concept of "happiness consists in contentment", as a kind of living philosophy in the phenomenon of surface form, it's wide and popular for a long time, which has a broad background and profound reasons. But, in front of the reality of helpless, "happiness consists in contentment" will only make people continuously 
for self- depressive, abandoning themselves, self-consolation. The concept has sharp opposition with the creative spirit and enterprising spirit required by modern movement. Socialist modern values takes pioneering innovation spirit and enterprising spirit, as well as eternal pursuit as the high performance of values of life. Therefore, in the social change, the traditional values of "happiness consists in contentment" must take a back seat in the stage of history behind the scenes, and the pioneering and enterprising spirit will change the reality and will become a value choice of new era.

\section{The Influence of Traditional Chinese Values on Ideological and Political Education}

Unyielding Enterprising Spirit. The man of honor will strive constantly for self-improvement. Here, it outlines the entrepreneurial spirits of energetic and promising, unyielding, daily renew and constant progress, which are the positive factors contained in China's important traditional values. This spirit is mainly embodied in the lofty ideal taking the world as its own duty to make the world peaceful and walk around the whole world for its great harmony, and as well as bear the suffering for the world, be contented in poverty and devoted to things spiritual without frustration or fear of setback, and struggle continuously towards life. The integrity and sentiment of great morality and justice has a very important role to cultivate students pioneering spirit. [8]

Realistic and Pragmatic Attitude to Reality. The Chinese emphasize the practical and neglect the contemplation, and are well known for their pragmatism. For thousands of years, Chinese people follow the sequence of four seasons, obey the rules of sunrise and sunset, with tillage on rural ridge and harvest in rural ridge, neither coveting the special gifts of nature, nor begging for soul asylum bless, completely getting the remuneration from the earth with industrious hands and labor. The moon and the sun coming again and again form the very realistic attitude of Chinese people. At the same time, the Confucian culture lay particular stress on ethics moral rationality and practical rationality as well as the long tradition of atheism, making Chinese easy to form the value orientation of humanistic pragmatism, focusing on practical effect against the vanity contemplation, namely the realistic and pragmatic spirit of reality. This has a very important role to cultivate matter-of-fact attitude of college students. [9]

Moral View of Humble Comity. Ritual is the ancient laws and regulations in feudal society, and social norms and moral principles. As a code of ethics, in the long history of development, it's integrated into the moral consciousness of working people, forming the link to maintain the harmonious unity of people, and the way for people to express their heart respect, especially the modest and gentle morality is passed on by Chinese people from generation to generation. It will help students establish a correct concept of ideological thinking, adhere to the correct behavior norms, in turn, build a harmonious society, and transfer socialist positive energy to strengthen "the ritual" education in ideological and political education of contemporary college students. [10]

\section{Summary}

In the process of ideological and political education in colleges and universities, in addition to strengthening the education of traditional culture, the traditional education and the usage in the process of ideological and political education should be given more attention. To the education of college students in the aspect of systematic traditional culture should be emphasized, at the same time, traditional culture needs to be used for carrying out the ideological and political education for contemporary college students, with more attention to the combination of traditional and real life. Traditional culture should be analyzed to strengthen the fusion of traditional culture and professional disciplines, and traditional culture connotation should be dug. Make the traditional culture lead the ideological and political education theory to get rid of the stale and bring forth the fresh, and innovate. 


\section{References}

[1] T.P.Bai: On campus culture of colleges and universities [M]. Beijing: China Forestry Publishing House, 2000(1) (In Chinese)

[2] X.H.Zhang, K.B.Shi: Chinese Traditional Culture and the Innovation of Ideological and Political Education [J]. Journal of Southeast University (philosophy and social sciences edition), 2008(5):56-59. (In Chinese)

[3] C.Y.Chi, J.Q.Wu: On Chinese Traditional Culture and the Ideological and Political Education of College Students [J].Journal of Beijing Youth Politics College, 2008(3):62-68.(In Chinese)

[4] Z.Y. Li: The Value of Traditional Culture in Ideological and Political Education and Its Implementation [D].Northeast Normal University, 2008. (In Chinese)

[5] H.X. Zhang: Actual Effect Research of the Ideological and Political Education of Colleges and Universities under the Background of Cultural Diversity [D].Shanxi Normal University, 2009. (In Chinese)

[6] L.P. Zheng: Playing the Role of Excellent Traditional Culture in Ideological and Political Education [J]. Journal of Education, 2007,(11):87-90. (In Chinese)

[7] L.P.Wang, F.Wang: Study on Carrying Forward the Traditional Culture Spirit in Ideological and Political Education [J]. Journal of Inner Mongolia Normal University (education sciences), 2007(11):61-67. (In Chinese)

[8] R.Jin: Chinese on traditional culture and contemporary youth development [J]. The Beijing education, 2011 (10). (In Chinese)

[9] G.Z.Yu, Z.X.Peng Chinese traditional culture in college students' cultural quality education [J]. Journal of Huangshi Institute of Technology, 2005 (4). (In Chinese)

[10]L.P.Zhu: University of traditional culture education [J] .Chinese dilemma of higher education, 2008 (22). (In Chinese) 